Volume 12, Nomor 2, November 2020, pp 265-276 Copyright (C) 2017

Jurnal Akuntansi, Program Studi Akuntansi, Fakultas Ekonomi, Universitas Kristen Maranatha. ISSN 2085-8698 | e-ISSN 2598-4977. http://journal.maranatha.edu

\title{
Pengaruh Pajak Tangguhan Dan Perencanaan Pajak Terhadap Kinerja Perusahaan
}

\author{
Fransiscus Felix Bhaktiar ${ }^{1}$ \\ Fakultas Ekonomi Program Studi Magister Akuntansi Universitas Kristen Maranatha \\ (Jl. Prof. drg. Suria Sumantri, MPH No. 65, Bandung) \\ fransiscus.felix.bhaktiar@gmail.com \\ Vinny Stephanie Hidayat ${ }^{2}$ \\ Fakultas Ekonomi Program Studi Akuntansi Universitas Kristen Maranatha \\ (Jl. Prof. drg. Suria Sumantri, MPH No. 65, Bandung) \\ vinny.tan@yahoo.co.id
}

\begin{abstract}
This study aims to examine deferred tax and tax planning on company performance. This study has a population in the form of companies listed on the Indonesia Stock Exchange during the 2014-2018 period. The sampling technique used was purposive. In analyzing the data, the technique used was multiple regression, with a significance level of 5\%. This study concludes that there is no partial or simultaneous influence between deferred tax and tax planning on company performance.
\end{abstract}

Keywords: Deferred Tax, Tax Planning, Company Performance

\begin{abstract}
Abstrak
Penelitian ini bertujuan untuk menguji pajak tangguhan serta perencanaan pajak pada kinerja perusahaan. Penelitian ini memiliki populasi berupa perusahaan yang terdaftar di Bursa Efek Indonesia selama periode 2014-2018. Teknik sampling yang digunakan adalah teknik purposive sampling. Dalam menganalisis data, teknik yang dipakai berupa regresi berganda, dengan tingkat signifikansi 5\%. Penelitian ini memiliki kesimpulan bahwa tidak terdapat pengaruh secara parsial maupun simultan antara pajak tangguhan serta perencanaan pajak terhadap kinerja perusahaan.
\end{abstract}

Kata Kunci: Pajak Tangguhan, Perencanaan Pajak, Kinerja Perusahaan 


\section{Pendahuluan}

Pada tahun 2019 terdapat beberapa perusahaan yang delisting dari Bursa Efek Indonesia (BEI). Salah satu perusahaan delisting yang menarik perhatian ialah PT Sigmagold Inti Perkasa Tbk (TMPI). TMPI telah berada di bursa selama 24 tahun. BEI mengeluarkan TMPI dari bursa dikarenakan belum membayar listing fee dan terdapat masalah going concern pada perusahaan. Bila ditelaah lebih lanjut, TMPI memiliki masalah berupa pendapatan yang berkurang disertai dengan beban pajak dan denda pajak yang naik secara signifikan sehingga menyebabkan kerugian (CNBC Indonesia, 2019). Berkaca dari kasus diatas, pengendalian atas kinerja perusahaan serta pengelolaan atas aspek perpajakan menjadi hal yang tidak dapat dihindarkan.

Pengendalian adalah kegiatan manajemen berupa pengawasan dan koreksi pada kinerja atau hasil dari pekerjaan (Robbins \& Coulter, 2018). Aspek keuangan merupakan sorotan utama dari pengendalian karena menggambarkan tujuan dalam menjalankan bisnis yaitu keuntungan atau laba. Dalam rangka memenuhi tujuan tersebut maka diperlukanlah akuntansi. Akuntansi adalah sebuah sistem yang didalamnya terdapat kegiatan mengidentifikasi, mengukur, mencatat serta mengkomunikasikan kegiatan bisnis organisasi (Wild \& Shaw, 2018). Produk yang dihasilkan oleh akuntansi merupakan informasi keuangan dalam bentuk laporan keuangan. Laporan keuangan yang dihasilkan tersebut dapat digunakan oleh pengguna internal maupun pengguna eksternal (Weygrandt, Kimmel, \& Kieso, 2018).

Pengguna internal laporan keuangan merupakan manajer dalam perusahaan yang menjalankan bisnis. Manajer yang memerlukan informasi keuangan tidak hanya sebatas manajer keuangan namun manajer pada bidang lain seperti marketing, produksi, atau pun company officers lainnya (Weygrandt, Kimmel, \& Kieso, 2018).
Sedangkan pengguna eksternal laporan keuangan sangat berangam. Mulai dari pemberi pinjaman, investor, boards of directors, external auditor, regulator hingga pelanggan (Wild \& Shaw, 2018). Setiap pengguna laporan keuangan baik eksternal maupun internal memiliki kepentingan yang berbeda-beda.

Kepentingan investor atas laporan keuangan untuk memperkirakan keuntungan atau laba yang akan diterima (Sodikin \& Riyono, 2012). Salah satu cara untuk mengukur keuntungan atau laba dapat melalui rasio keuangan. Rasio keuangan merupakan alat yang menyediakan pandangan terhadap kondisi yang mendasar (Subramanyam, 2014). Kondisi yang mendasar tersebut dapat menunjukkan kekuatan dan kelemahan keuangan suatu bisnis (Atrill, 2020). Rasio keuangan yang dipakai dalam mengukur keuntungan dinamakan rasio profitabilitas. Terdapat beberapa rasio yang termasuk dalam rasio profitabilitas, salah satunya adalah Return on Equity (ROE). Rasio ini berguna untuk mengetahui seberapa besar persentase pengembalian investasi aktual dibuat oleh pemegang saham (Stice \& Stice, 2012).

Kepentingan lain atas laporan keuangan datang dari regulator atau negara (pihak ekternal). Negara memiliki kepentingan untuk menarik pajak dari bisnis. Pajak merupakan iuran wajib yang terutang bagi pribadi maupun badan, bersumber dari undang-undang namun tidak memiliki timbal balik secara langsung pada pribadi atau badan. Terdapat beberapa jenis pajak yang ditarik oleh negara, yang terbesar adalah pajak penghasilan. Pajak penghasilan adalah pajak yang ditarik atas penghasilan subjek pajak yang menerima atau memperoleh penghasilan pada satu tahun pajak. Negara memiliki kepentingan serta kekuasaan yang signifikan dalam menarik pajak.

Dari sisi perusahaan, pajak dinilai sebagai beban sehingga berusaha seoptimal mungkin dalam pembayarannya. Dengan pajak sebagai beban dari perusahaan, maka 
pembayaran pajak akan mengurangkan laba dari perusahaan. Berdasarkan dampak perpajakan terhadap bisnis maka diperlukannya perencanaan pajak. Perencanaan pajak adalah cara-cara mengelola utang pajak agar berada pada jumlah yang minimum namun tidak melanggar peraturan yang ada (Pohan, 2013). Tujuan dari perencanaan pajak ialah untuk menambah tingkat profitabilitas perusahaan, sehingga lebih banyak menarik investor (Sipahi, 2020). Selain menarik investor, perencanaan pajak digunakan untuk meningkatkan kinerja dari perusahaaan (Olarewaju \& Olayiwola, 2019). Terdapat beberapa cara dalam menilai apakah perencanaan pajak perusahaan tersebut baik atau tidak. Secara umum perencanaan pajak diukur melalui effective tax rate ataupun book tax defference. Selain dua cara tersebut, terdapat cara lain mengukur perencanaan pajak yaitu menghitung tax to book ratio. Tax to book ratio adalah rasio perbandingan antara laba kena pajak (laba fiskal) dan laba akuntansi (Harmana \& Suardana, 2014). Laba kena pajak dan laba akuntansi memiliki perbedaan karena peraturan undang-undang terutama dalam bidang perpajakan (Suprianto, 2011). Dalam tax to book ratio semakin laba fiskal mendekati laba akuntansi maka semakin baik perencanaan pajak perusahaan tersebut (Harmana \& Suardana, 2014). Sebaliknya perbedaan yang besar antara laba fiskal dan laba akuntansi akan menaikkan beban pajak tangguhan (Marpaung \& Tjun, 2016).

Pajak tangguhan adalah jumlah antisipasi pajak terhutang yang dapat timbul di saat ini atau di masa depan sebagai akibat dari utang pajak penghasilan yang pengakuannya ditunda (Sibarani, Hidayat, \& Surtikanti, 2015). Pajak tangguhan merupakan akibat dari perbedaan pengakuan antara pengakuan secara perpajakan dengan pengakuan akuntansi (Spiceland, Nelson, \& Thomas, 2018). Pengakuan pajak tangguhan memunculkan beban pajak tangguhan atau manfaat pajak tangguhan yang dapat menambah atau mengurangi laba bersih (Purba, 2009).

Terdapat beberapa penelitian mengenai pajak tangguhan dan perencanaan pajak. Casanova dan Marsellisa (2014) meneliti kinerja laporan keuangan perusahaan yang dipengaruhi oleh aktiva pajak tangguhan serta rasio tax to book. Kinerja perusahaan diukur menggunakan return on assets (ROA). Penelitian ini memakai 24 perusahaan dengan periode 2009-2011 sebagai sampelnya. Casanova dan Marsellisa (2014) menyimpulkan bahwa dengan terdapatnya akun baru dalam laporan keuangan berupa akun pajak tangguhan memberikan penambahan nilai perhitungan ROA sehingga menyebabkan pajak tangguhan berpengaruh terhadap kinerja keuangan. Sedangkan variabel tax to book ratio juga berpengaruh terhadap kinerja perusahaan. Kinerja perusahaan akan turun saat tax to book ratio bertambah karena pembayaran pajak akan meningkat.

Penelitan Harmana \& Suardana (2014) memiliki persamaan dengan penelitian Casanova dan Marsellisa (2014). Namun variabel independen yang dipakai berupa return of investment (ROI). Periode penelitian pun lebih singkat yaitu dari tahun 2010-2011. Namun sampel penelitian lebih banyak sebesar 33 perusahaan manufaktur. Harmana \& Suardana (2014) menemukan bahwa pajak tangguhan membantu kinerja perusahaan. Sedangkan pada variabel tax to book ratio, peneliti menduga periode waktu penelitian yang singkat menyebabkan tidak ditemukan pengaruh dengan kinerja keuangan.

Penelitian lain dilakukan oleh Razali, Ghazali, Lunyai, \& Hwang (2018) mengenai perencanaan pajak dan nilai perusahaan. Penelitian ini menggunakan dua cara menghitung perencanaan pajak yaitu effective tax rate dan book tax differences. Sedangkan variabel nilai perusahaan diukur melalui rasio Tobin $\mathrm{Q}$. Tobin Q sendiri merupakan indikator dalam mengukur kinerja perusahaan dari sisi pengelolaan aset perusahaan. Sampel 
penelitian ini berjumlah 387 sampel dengan periode 2014-2016. Hasil penelitian menemukan bahwa book tax differences tidak memiliki pengaruh pada nilai perusahaan. Sebaliknya variabel effective tax rate memiliki pengaruh terhadap nilai perusahaan.

Nwaorgu, Abiahu, Tapang, \& Lormbaga (2019) meneliti pajak tangguhan dan kinerja keuangan perusahaan agrikultur di Nigeria. Penelitian ini memiliki tiga cara mengukur kinerja keuangan yaitu dengan profitabilitas (laba setelah pajak), arus kas dan earning per share. Sementara variabel independennya berupa pajak tangguhan. Periode penelitian ini selama tujuh tahun dari 2011-2017 dengan sampel penelitian empat perusahaan. Hasil yang didapat berupa pajak tangguhan berpengaruh terhadap profitabilitas. Disisi lain pajak tangguhan tidak memiliki pengaruh terhadap arus kas dan earning per share.

Berdasarkan uraian di atas, penulis melakukan penelitian mengenai pengaruh pajak tangguhan dan perencanaan pajak terhadap kinerja perusahaan karena terdapat ketidakkonsistenan dari hasil penelitianpenelitian terdahulu. Periode penelitian ini selama lima tahun (2014-2018) dengan populasi penelitian perusahaan yang terdaftar di Bursa Efek Indonesia selama kurun waktu tersebut.

\section{Kerangka Teoritis dan Hipotesis}

\section{Laporan Keuangan}

Laporan keuangan adalah sumber informasi yang berasal dari proses akuntansi yang berguna untuk mengambil keputusan dalam bidang ekonomi bagi yang memakainya (Sodikin \& Riyono, 2012). Informasi yang dapat didapat dari laporan keuangan antara lain (Sari, 2014):

1. Memberikan informasi mengenai Neraca sebuah perusahaan (aset, kewajiban, dan modal);

2. Memberikan informasi mengenai perubahan aset neto (aset dikurangi kewajiban) dalam suatu perusahaan sebagai akibat dari kegiatan usaha yaitu memperoleh laba;

3. Memberikan informasi mengenai memperkirakan potensi laba suatu perusahaan;

4. Memberikan informasi penting lainnya, seperti informasi mengenai aktivitas pembiayaan dan investasi;

5. Mengungkapkan informasi yang berhubungan dan relevan mengenai laporan keuangan bagi pengguna laporan.

Laporan keuangan yang dihasilkan tersebut dapat digunakan oleh pengguna internal maupun pengguna ekternal (Weygrandt, Kimmel, \& Kieso, 2018). Setiap pengguna laporan keuangan baik eksternal maupun internal memiliki kepentingan yang berbeda-beda. Bagi manajemen dan investor, laporan keuangan digunakan untuk memperkirakan keuntungan atau laba yang akan diterima (Sodikin \& Riyono, 2012).

\section{Rasio Keuangan}

Salah satu cara untuk mengukur keuntungan atau laba dapat melalui rasio keuangan. Rasio keuangan merupakan alat yang menyediakan pandangan terhadap kondisi yang mendasar (Subramanyam, 2014). Kondisi yang mendasar tersebut dapat menunjukan kekuatan dan kelemahan keuangan suatu bisnis (Atrill, 2020). Terdapat 5 kelompok dalam rasio keuangan yaitu (Atrill, 2020):

1. Rasio profitabilitas

Rasio profitabilitas menyediakan ramburambu mengenai tingkat keberhasilan dalam mencapai tujuan bisnis yaitu memperoleh keuntungan.

2. Rasio efisiensi

Rasio efisiensi disebut juga sebagai rasio aktivitas. Rasio efisiensi bertujuan mengukur ketepatgunaan dari sumber daya yang digunakan.

3. Rasio likuiditas

Rasio likuiditas sangat penting bagi kelangsungan karena menyediakan informasi sumberdaya yang dapat dipakai 
segera untuk menutupi kewajiban membayar dalam waktu yang dekat.

4. Rasio financial gearing

Rasio ini berfokus pada hubungan kontribusi pendanaan yang dipakai bisnis baik dari pemilik atau dari pinjaman.

5. Rasio investasi

Rasio investasi berfokus pada menilai tingkat pengembalian dan kinerja dari saham dari sudut pandang pemengang saham.

Bagi investor kelancaran dan kemampuan perusahaan dalam menghasilkan keuntungan merupakan hal yang penting (Fahmi, 2014). Rasio keuangan yang dipakai dalam mengukur keuntungan dinamakan rasio profitabilitas. Terdapat beberapa rasio yang termasuk dalam rasio profabilitas, salah satunya adalah Return on Equity (ROE). Rasio ini berguna untuk mengetahui seberapa besar persentase pengembalian investasi aktual dibuat oleh pemegang saham (Stice \& Stice, 2012). Return on equity dihasilkan dari pembagian antara laba bersih dengan total ekuitas (Stice \& Stice, 2012).

\section{Perencanaan Pajak}

Laba juga merupakan dasar bagi penghitungan pajak. Pajak merupakan iuran wajib yang terutang bagi pribadi maupun badan, bersumber dari undang-undang namun tidak memiliki timbal balik secara langsung pada pribadi atau badan. Dengan dianggapnya pajak sebagai beban dari perusahaan, maka pembayaran pajak akan mengurangkan laba dari perusahaan. Berdasarkan dampak perpajakan terhadap bisnis maka diperlukannya perencanaan pajak. Perencanaan pajak adalah cara-cara mengelola utang pajak agar berada pada jumlah yang minimum namun tidak melanggar peraturan yang ada (Pohan, 2013) Terdapat tiga strategi umum dalam sebuah perencanaan pajak yaitu (Spilker, et al., 2018):

\section{Timing}

Strategi mempercepat atau memperlambat pendapatan kena pajak atau pengurangan pajak.

\section{Income shifting}

Strategi pengalihan pendapatan dari wajib pajak tingkat tinggi ke pajak rendah.

\section{Convertion}

Strategi mengubah pendapatan dari aktivitas dengan tarif pajak tinggi ke rendah.

Terdapat beberapa cara dalam menilai apakah perencanaan pajak perusahaan tersebut baik atau tidak. Secara umum perencanaan pajak diukur melalui effective tax rate ataupun book tax defference. Selain dua cara tersebut, terdapat cara lain mengukur perencanaan pajak yaitu menghitung tax to book ratio. Tax to book ratio adalah rasio perbandingan antara laba kena pajak (laba fiskal) dan laba akuntansi (Harmana \& Suardana, 2014). Laba kena pajak dan laba akuntansi memiliki perbedaan karena peraturan undang-undang terutama dalam bidang perpajakan (Suprianto, 2011). Dalam tax to book ratio semakin laba fiskal mendekati laba akuntansi maka semakin baik perencanaan pajak perusahaan tersebut (Harmana \& Suardana, 2014). Sebaliknya perbedaan yang besar antara laba fikal dan laba akuntansi akan menaikan beban pajak tangguhan (Marpaung \& Tjun, 2016).

\section{Pajak Tangguhan}

Pajak tangguhan adalah jumlah antisipasi pajak terhutang yang dapat timbul di saat ini atau di masa depan sebagai akibat dari utang pajak penghasilan yang pengakuannya ditunda (Sibarani, Hidayat, \& Surtikanti, 2015). Pajak tangguhan digolongkan menjadi dua yaitu aktiva pajak tangguhan dan kewajiban pajak tangguhan. Aktiva pajak tangguhan adalah manfaat yang diharapkan di masa depan dari potongan pajak yang telah diakui sebagai biaya dalam laporan laba rugi tapi belum dikurangkan untuk tujuan pajak pendapatan 
(Stice \& Stice, 2012). Sementara itu kewajiban pajak tangguhan adalah perkiraan pendapatan yang dipajaki di masa depan yang telah diakui pada laporan laba rugi tapi belum dikenai pajak (Stice \& Stice, 2012). Pengakuan pajak tangguhan memunculkan beban pajak tangguhan atau manfaat pajak tangguhan yang dapat menambah atau mengurangi laba bersih (Purba, 2009).

\section{Rerangka Penelitian}

Berdasarkan penjelasan diatas, maka peneliti menyajikan rerangka pemikiran sebagai berikut:

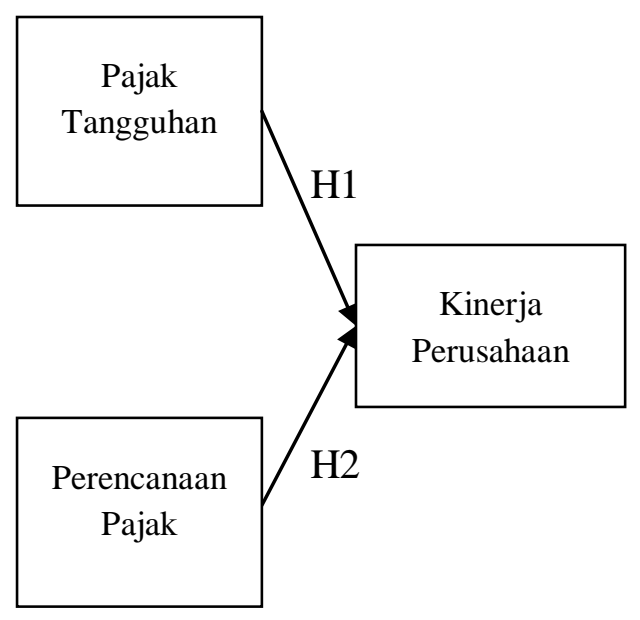

\section{Gambar 1 \\ Model Penelitian}

Berdasarkan kajian pustaka di atas, maka hipotesis dalam penelitian ini adalah:

H1: Pajak Tangguhan berpengaruh terhadap kinerja perusahaan.

H2: Perencanaan pajak berpengaruh terhadap kinerja perusahaan.

\section{Metode Penelitian}

Penelitian ini adalah penelitian kausal (hubungan sebab akibat). Penelitian causalexplanatory adalah penelitian yang mempelajari bagaimana suatu variabel dapat memberikan perubahan pada variabel lain (sebab akibat) (Cooper \& Schindler, 2014). Cara pengumpulan data yang dipakai berupa data arsip (archival). Populasi dalam penelitian ini adalah perusahaan-perusahaan yang terdaftar di Bursa Efek Indonesia (BEI) selama periode 2014-2018, dengan total jumlah populasi 649 perusahaan. Penelitian ini menggunakan non-probability sampling dengan metode purposive sampling. Purposive sampling merupakan cara pengambilan sampel non-probability yang bertujuan untuk melacak segala kemungkinan untuk kasus yang sangat spesifik (Neuman, 2014). Berikut adalah kriteria-kriteria dari sampel penelitian:

1. Perusahaan-perusahaan yang memperoleh laba berturut-turut selama tahun 20142018.

2. Perusahaan mempublikasikan laporan keuangan yang telah diaudit dengan mempergunakan tahun buku yang berakhir 31 Desember dan dinyatakan dalam mata uang Rupiah (Rp).

3. Mencantumkan beban pajak tangguhan perusahaan tahun 2014-2018.

4.Perusahaan sampel mencantumkan besarnya laba kena pajak pada laporan keuangan perusahaan tahun 2014-2018.

5.Perusahaan sampel tidak memiliki kompensasi kerugian selama tahun 20142018.

Berdasarkan kriteria diatas maka dihasilkan sampel sebanyak enam perusahaan dengan periode selama lima tahun (2014-2018). Maka data penelitian yang didapat sebanyak 30 buah (enam perusahaan dikali dengan 5 tahun).

Pada penelitian ini, pajak tangguhan dan perencanaan pajak yang diukur dengan tax to book ratio merupakan variabel independen, sedangkan kinerja perusahaan yang diukur dengan return on equity 
sebagai variabel dependen. Berikut tabel definisi operasional variabel penelitian ini:

\section{Variabel Penelitian}

1. Variabel Independen

a. Pajak Tangguhan

Pajak tangguhan adalah jumlah antisipasi pajak terhutang yang dapat timbul di saat ini atau di masa depan sebagai akibat dari utang pajak penghasilan yang pengakuannya ditunda (Sibarani, Hidayat, \& Surtikanti, 2015). Rumus pajak tangguhan menurut Harmana \& Suardana (2014):

\section{Beban Pajak Tangguhan Rata - rata Total Asset}

\section{b. Tax to book ratio}

Tax to book ratio adalah rasio perbandingan antara laba kena pajak (laba fiskal) dan laba akuntansi (Harmana \& Suardana, 2014). Rumus tax to book ratio:

\section{Laba Kena Pajak \\ Laba Sebelum Pajak}

\section{Variabel Dependen}

Return on equity dihasilkan dari pembagian antara laba bersih dengan total ekuitas (Stice \& Stice, 2012). Rumus ROE:

\section{$\frac{\text { Laba Bersih }}{\text { Totol Elwitas }}$}

Penelitian ini menggunakan metode analisis data berupa regresi berganda, uji signifikansi simultan, uji signifikansi parameter individual, dan uji goodness of fit. Regresi berganda menyediakan cara untuk menilai secara objektif derajat dan hubungan antara variabel independen dan variabel dependen (Sekaran \& Bougie, 2016). Sedangkan uji signifikansi parameter individual bertujuan mengetahui kemungkinan hubungan antara masingmasing variabel bebas dan variabel terikat (Saunders, Lewis, \& Thornhill, 2019). Uji signifikansi simultan menunjukkan kemungkinan hubungan antara variabel independen dan variabel dependen secara keseluruhan (Saunders, Lewis, \& Thornhill, 2019). Terakhir uji goodness of fit bertujuan menunjukkan seberapa baik data menjelaskan model penelitian (Cooper \& Schindler, 2014).

Dalam pemakaian regresi berganda, terdapat persyaratan statistik yang harus dipenuhi berupa lolos uji asumsi klasik. Setidaknya ada lima uji asumsi klasik yaitu uji normalitas, uji Outlier, uji multikolineritas, uji heteroskedastisitas, dan uji autokorelasi, namun tidak semua uji asumsi klasik harus dilakukan pada regresi berganda (Sunjoyo, Setiawan, Carolina, Magdalena, \& Kurniawan, 2013).

Pada penelitian ini, uji asumsi klasik yang dipakai adalah:

1. Uji normalitas diperlukan untuk mengetahui variabel dependen dan variabel independen memiliki pola distribusi frekuensi yang berbentuk seperti lonceng yang merupakan syarat dari uji parametrik (Saunders, Lewis, \& Thornhill, 2019).

2. Uji multikolinearitas diperlukan untuk mengetahui hubungan antar variabel independen, masalah multikolinearitas akan menyulitkan memisahkan pengaruh antar tiap varabel (Saunders, Lewis, \& Thornhill, 2019).

3. Uji heteroskedastisitas diperlukan untuk mengetahui model regresi terjadi ketidaksamaan varians dari residual suatu pengamatan ke pengamatan lain (Umar, 2013).

4. Uji autokorelasi diperlukan untuk mengetahui sebuah model regresi liner terdapat hubungan yang kuat baik positif maupun negatif antara data yang ada pada variabel-variabel penelitian (Umar, 2013). 


\section{Hasil Penelitian dan Pembahasan}

Berikut merupakan hasil dari pengujian uji asumsi klasik (uji normalitas, uji autokorelasi, uji multikolinearitas, dan uji heteroskedastisitas):

\section{Tabel 1}

Hasil Uji Asumsi Klasik 1

\begin{tabular}{|l|l|l|}
\hline $\begin{array}{l}\text { Nama } \\
\text { Penguji } \\
\text {-an }\end{array}$ & $\begin{array}{l}\text { Uji } \\
\text { Normalitas }\end{array}$ & $\begin{array}{l}\text { Uji } \\
\text { Autokorelasi }\end{array}$ \\
\cline { 1 - 2 } Metode & $\begin{array}{l}\text { Kolmogorov- } \\
\text { Smirnov }\end{array}$ & $\begin{array}{l}\text { Durbin } \\
\text { Watson }\end{array}$ \\
\hline Kriteria & $\begin{array}{l}\text { Asymp. Sig. } \\
(2 \text {-tailed) } \\
0.05\end{array}$ & Du<d<4-Du \\
\hline Hasil Pengujian: & $1.567^{*}<1.648$ \\
\hline $\begin{array}{l}\text { Variabe } \\
\text { DT }\end{array}$ & .431 & $<2.433$ \\
\cline { 1 - 1 } $\begin{array}{l}\text { Variabe } \\
\text { 1 TBR }\end{array}$ & & \\
\cline { 1 - 2 } $\begin{array}{l}\text { Kesimp } \\
\text { ulan }\end{array}$ & Lolos & Lolos \\
\hline
\end{tabular}

Tabel 2

Hasil Uji Asumsi Klasik 2

\begin{tabular}{|c|c|c|c|}
\hline $\begin{array}{l}\text { Nama } \\
\text { Penguji- } \\
\text { an }\end{array}$ & \multicolumn{2}{|c|}{$\begin{array}{l}\text { Uji } \\
\text { Multikolineari- } \\
\text { tas }\end{array}$} & $\begin{array}{l}\text { Uji } \\
\text { Hetero- } \\
\text { skedasti- } \\
\text { sitas }\end{array}$ \\
\hline Metode & \multicolumn{2}{|l|}{-} & Glejser \\
\hline Kriteria & $\begin{array}{l}\text { Toleran } \\
\text { ce } \\
>0.1\end{array}$ & $\begin{array}{l}\text { VIF } \\
\leq 10\end{array}$ & $\begin{array}{l}\text { Sig. > } \\
0.05\end{array}$ \\
\hline \multicolumn{4}{|c|}{ Hasil Pengujian: } \\
\hline $\begin{array}{l}\text { Variabel } \\
\text { DT }\end{array}$ & .995 & 1.005 & .093 \\
\hline $\begin{array}{l}\text { Variabel } \\
\text { TBR }\end{array}$ & .995 & 1.005 & .940 \\
\hline $\begin{array}{l}\text { Kesimpul } \\
\text { an }\end{array}$ & Lolos & Lolos & Lolos \\
\hline
\end{tabular}

Berikut merupakan hasil dari pengujian uji signifikansi parameter individual, uji signifikansi simultan, uji goodness of fit dan uji regresi berganda:

Tabel 3

Hasil Analisis Data 1

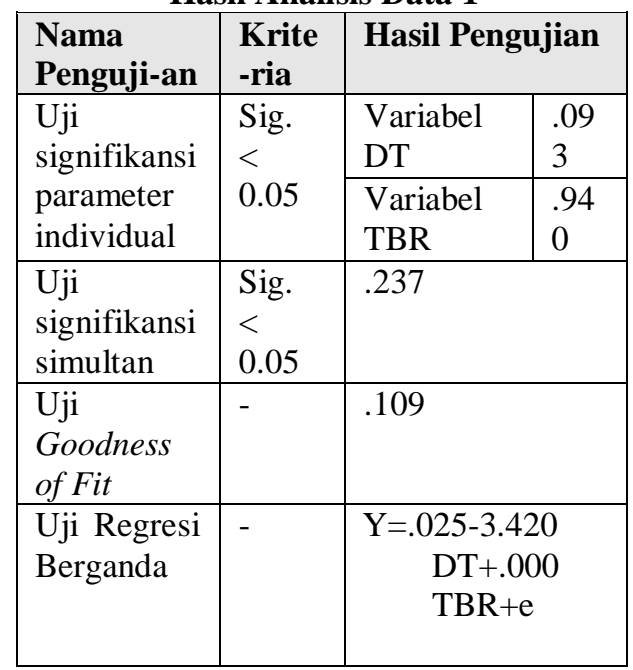


Tabel 4

Hasil Analisis Data2

\begin{tabular}{|c|c|}
\hline $\begin{array}{l}\text { Nama } \\
\text { Pengujian }\end{array}$ & Keterangan \\
\hline \multirow{2}{*}{$\begin{array}{l}\text { Uji signifikansi } \\
\text { parameter } \\
\text { individual }\end{array}$} & Tidak berpengaruh \\
\hline & Tidak berpengaruh \\
\hline $\begin{array}{l}\text { Uji signifikansi } \\
\text { simultan }\end{array}$ & Tidak berpengaruh \\
\hline $\begin{array}{l}\text { Uji Goodness of } \\
\text { Fit }\end{array}$ & 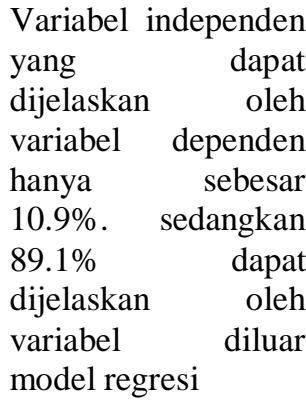 \\
\hline
\end{tabular}

Catatan:

DT = pajak tangguhan

TBR $=$ tax to book ratio

\section{Pengaruh Pajak Tangguhan Terhadap Kinerja Perusahaan}

Secara teoritis pajak tangguhan berpengaruh terhadap kinerja perusahaan. Untuk menguji hipotesis di atas, digunakan kriteria pengujian dua sisi adalah sebagai berikut:

Nilai Signifikansi $\leq$ Taraf Signifikansi $(\alpha)$ : $\mathrm{H}_{0}$ Ditolak

Nilai Signifikansi $>$ Taraf Signifikansi $(\alpha)$ : $\mathrm{H}_{0}$ Diterima

Berdasarkan tabel 3 nilai signifikansi diperoleh sebesar .093 dan taraf signifikansi sebesar .050. Nilai signifikansi yang diperoleh .093 lebih daripada taraf signifikansi sebesar .050, maka disimpulkan bahwa $\mathrm{H}_{0}$ diterima. $\mathrm{H}_{0}$ diterima berarti pajak tangguhan tidak mempunyai pengaruh terhadap kinerja perusahaan.
Hasil dari penelitian ini mendukung penelitian dari Nwaorgu, Abiahu, Tapang, \& Lormbaga (2019) dimana pajak tangguhan dapat tidak berpengaruh pada kinerja perusahaan. Pajak tangguhan memiliki karakteristik yang dapat menambah atau mengurangi laba bersih (Purba, 2009). Penyebab pajak tangguhan adalah perbedaaan sementara pengakuan antara akuntansi komersial dengan undangundang perpajakan. Perbedaan sementara yang paling sering terjadi antara pengakuan akuntansi dan undang-undang perpajakan adalah penyusutan dan amortisasi (Wijayanti, 2016). Secara akuntansi komersial, pemilihan metode penyusutan dan umur manfaat sebuah aset tetap ditentukan oleh manajemen sesuai dengan estimasi pola pemakaian aset tetap di masa depan. Namun pada undang-undang perpajakan metode penyusutan dibatasi menjadi metode garis lurus dan metode saldo menurun ganda. Sedangkan untuk penentuan umur manfaat ditentukan dengan kategori tertentu yang setiap kategori memiliki umur manfaat yang berbeda (secara garis besar kategori aset dibagi atas bangunan dan non bangunan, untuk bangunan dibagi atas permanen dan tidak permanen, sedangkan untuk bukan bangunan dibagi menjadi 4 kelompok). Perbedaan tersebut menjadikan beban penyusutan secara akuntansi komersial dan undang-undang perpajakan berbeda pada sepanjang umur manfaat namun secara keseluruhan jumlahnya tetap sama. Perbedaan sementara tersebut menyebabkan pajak tangguhan tidak berpengaruh terhadap laba (Wijayanti, 2016). Hasil penelitian ini bertentangan dengan penelitian Harmana \& Suardana (2014) serta Casanova \& Nindito (2014). 


\section{Pengaruh Perencanaan Pajak Terhadap Kinerja Perusahaan}

Secara teoritis perencanaan pajak berpengaruh terhadap kinerja perusahaan. Untuk menguji hipotesis di atas, digunakan kriteria pengujian dua sisi adalah sebagai berikut:

Nilai Signifikansi $\leq$ Taraf Signifikansi $(\alpha)$ : $\mathrm{H}_{0}$ Ditolak

Nilai Signifikansi $>$ Taraf Signifikansi $(\alpha)$ : $\mathrm{H}_{0}$ Diterima

Berdasarkan tabel 3 nilai signifikasi diperoleh sebesar .943 dan taraf signifikasi sebesar .050. Nilai signifikansi yang diperoleh sebesar .940 lebih besar daripada taraf signifikansi sebesar 0.05, maka disimpulkan $\mathrm{H}_{0}$ diterima. $\mathrm{H}_{0}$ diterima artinya perencanaan pajak tidak mempunyai pengaruh terhadap kinerja perusahaan. Hasil penelitian ini bertentangan dengan penelitian Casanova \& Nindito (2014). Namun hasil dari penelitian ini mendukung penelitian yang dilakukan oleh Harmana \& Suardana (2014) dan Razali, Ghazali, Lunyai, \& Hwang (2018) yang menyatakan perencanaan pajak tidak berpengaruh pada kinerja perusahaan. Perencanaan pajak adalah cara-cara mengelola utang pajak agar berada pada jumlah yang minimum namun tidak melanggar peraturan yang ada (Pohan, 2013). Perencanaan pajak diharapkan akan meningkatkan kinerja perusahaan (Olarewaju \& Olayiwola, 2019) sehingga menambah tingkat profitabilitas perusahaan, yang pada akhirnya akan lebih banyak menarik investor (Sipahi, 2020). Berdasarkan perhitungan statistik, perencanaan pajak tidak berpengaruh terhadap kinerja perusahaan. Perhitungan penghindaran pajak penelitian ini menggunakan tax to book ratio atau rasio perbandingan antara laba kena pajak (laba fiskal) dan laba akuntansi. Menurut Hanlon \& Heitzman (2010), penghitungan seperti ini hanya dapat menangkap sebagian unsur dari perencanaan pajak. Unsur yang dimaksud adalah perbedaan sementara dari perencanaan pajak, sehingga tidak tepat untuk digunakan antar perusahaan yang memiliki berbagai kepentingan yang berbeda atas laba akuntansi. Hasil ini penelitian ini juga menunjukan bahwa masih terdapat faktor lain yang mempengaruhi kinerja perusahaan. Koller, Dobbs, \& Huyett (2011) menyatakan bahwa perusahaan harus dapat lebih banyak menghasilkan uang dimasa depan bagi pemiliknya yang telah berinvestasi yang didorong oleh return on invested capital, revenue growth dan arus kas disertai kemampuan mempertahankannya.

\section{Simpulan dan Saran}

\section{Simpulan}

Penelitian ini meneliti mengenai pengaruh pajak tangguhan dan perencanaan pajak terhadap kinerja perusahaan. Periode penelitian ini selama lima tahun dari tahun 2014-2018. Berdasarkan perhitungan statistik maka ditarik kesimpulan, pertama pajak tangguhan tidak memiliki pengaruh terhadap kinerja perusahaan. Kedua, perencanaan pajak tidak memiliki pengaruh terhadap kinerja perusahaan. Ketiga, pajak tangguhan serta perencanaan pajak tidak memiliki pengaruh secara simultan terhadap kinerja perusahaan. Selain pada kesimpulan statistik, penelitian ini juga menunjukkan bahwa dalam jangka panjang (lima tahun) baik pajak tangguhan dan perencanaan pajak (tax to book ratio) tidak memiliki pengaruh pada perusahaan. Hal ini menunjukkan bahwa perusahaan tidak perlu berfikir terlalu jauh dalam perbedaan sementara yang timbul dan dapat mengalihkan fokusnya pada hal yang lain. 


\section{Keterbatasan}

Peneliti menyadari penelitian ini masih memiliki beberapa keterbatasan, yaitu:

1. Masih terdapat cara penghitungan lain selain return on equity untuk mengukur kinerja perusahaan.

2. Variabel independen yang digunakan hanya dua sehingga kurang menggambarkan pengaruhnya terhadap variabel dependen.

3. Variabel pajak tangguhan yang dipakai tidak dipisahkan antara aktiva pajak tangguhan atau kewajiban pajak tangguhan.

4. Variabel perencanaan pajak yang dipakai hanya berfokus pada perbedaan sementara akibat dari perbedaan pengakuan.

\section{Saran}

Berdasarkan hasil penelitian, saran yang dapat diberikan peneliti ialah:

1. Pengukuran kinerja perusahaan sebaiknya tidak terpaku pada profitabilitas, terdapat aspek lain yang patut dipertimbangkan seperti revenue growth, return on invested capital, dan arus kas.

2. Peneliti berikutnya diharapkan dapat menambah variabel independen lain dalam penelitian, seperti indikatorindikator kesehatan perusahaan (seperti likuiditas, leverage, solvabilitas dan lainlain) untuk melengkapi variabel perpajakan.

3. Peneliti berikutnya sebaiknya mempertimbangkan untuk memisahkan pajak tangguhan menjadi kewajiban pajak tangguhan dan aktiva pajak tangguhan disebabkan kedua akun tersebut memiliki dampak yang berbeda terhadap laba.

4. Peneliti berikutnya sebaiknya memakai metode lain yang dapat menangkap seluruh unsur penghindaran pajak.

\section{Daftar Pustaka}

Atrill, P. (2020). Financial Management for Decision Makers. New York: Pearson.

Casanova, B., \& Nindito, M. (2014). Pengaruh Aktiva Pajak Tangguhan Dan Rasio Pajak Terhadap Kinerja Laporan Keuangan Perusahaan Pada Perusahaan Yang Terdaftar Di Bursa Efek Indonesia. Jurnal Ilmiah Wahana Akuntansi, 80-108.

CNBC Indonesia. (2019, November 07). Sahamnya 99\% Dipegang Publik, tapi Delisting, kok Bisa? Retrieved from CNBC Indonesia: https://www.cnbcindonesia.com/mar ket/20191106131017-17113106/sahamnya-99-dipegangpublik-tapi-delisting-kok-bisa

Cooper, D. R., \& Schindler, P. S. (2014). Business Research Methods. New York: McGraw-Hill.

Fahmi, I. (2014). Analisis Laporan Keuangan. Bandung: Penerbit Alfabeta.

Hanlon, M., \& Heitzman, S. (2010). A Review of Tax Research. Journal of Accounting and Economics, 127178.

Harmana, I., \& Suardana, K. (2014). Pengaruh Pajak Tangguhan dan Tax To Book Ratio Terhadap Kinerja Perusahaan. E-Jurnal Akuntansi Universitas Udayana, 468-480.

Koller, T., Dobbs, R., \& Huyett, B. (2011). Value : The Four Cornerstones of Corporate Finance. Hoboken: JohnWiley \& Sons, Inc.

Marpaung, E., \& Tjun, L.T. (2016). Pengaruh Pajak Tangguan dan Tax To Book Ratio Terhadap Kinerja Perusahaan. Jurnal Akuntansi, 1638.

Neuman, W. L. (2014). Social Research Methods: Qualitative and Quantitative Approaches. Pearson Education Limited. 
Nwaorgu, I. A., Abiahu, M.-F. C., Tapang, A. T., \& Lormbaga, J. A. (2019). Deferred Tax Accounting and Financial Performance: The Listed Agricultural Firms Perspective in Nigeria.

Olarewaju, O. M., \& Olayiwola, J. A. (2019). Corporate Tax Planning and Financial Performance in Nigerian Non- Financial Quoted Companies. African Development Review, 202215.

Pohan, C. A. (2013). Manajemen Perpajakan. Jakarta: PT Gramedia Pustaka Utama.

Purba, M. (2009). Akuntansi Pajak Penghasilan. Yogyakarta: Graha Ilmu.

Razali, M. W., Ghazali, S. S., Lunyai, J., \& Hwang, Y. T. (2018). Tax Planning and Firm Value: Evidence from Malaysia. International Journal of Academic Research in Business and Social Sciences, 210-222.

Robbins, S. P., \& Coulter, M. (2018). Management. London: Pearson Education Limited.

Sari, D. (2014). Perpajakan Konsep, Teori, dan Aplikasi Pajak Penghasilan. Jakarta: Mitra Wacana Media.

Saunders, M., Lewis, P., \& Thornhill, A. (2019). Research methods for business students. New York: Pearson.

Sekaran, U., \& Bougie, R. (2016). Research methods for business : a skillbuilding approach. Chichester: John Wiley \& Sons.

Sibarani, T., Hidayat, N., \& Surtikanti. (2015). Analisis Pengaruh Beban Pajak Tangguhan, Discreianary Accruals, dan Arus Kas Operasi Terhadap Manajemen Laba. Jurnal Riset Akuntansi dan Perpajakan, 1931.

Sipahi, E. (2020). Tax Plannıng and Firm Value: An Empirical Analysis of Consumer Goods Manufacturing
Companıes in Cyprus. Socialsci Journal.

Sodikin, S., \& Riyono, B. (2012). Akuntansi Pengantar 1. Yogyakarta: Unit Penerbit dan Percetakan Sekolah Tinggi Ilmu Manajemen YKPN.

Spiceland, J. D., Nelson, M. W., \& Thomas, W. B. (2018). Intermediate Accounting. New York: McGrawHill Education.

Spilker, B., Ayers, B., Barrick, J., Outslay, E., Robinson, J., Weaver, C., \& Worsham, R. (2018). Taxation of Individuals and Business Entities. McGraw-Hill Education.

Stice, E. K., \& Stice, J. D. (2012). Intermediate Accounting. Mason: South-Western Cengage Learning.

Subramanyam, K. R. (2014). Financial Statment Analysis. New York: McGraw-Hill Education.

Sunjoyo, Setiawan, R., Carolina, V., Magdalena, N., \& Kurniawan, A. (2013). Aplikasi SPSS untuk SMART Riset. Bandung: Alfabeta.

Suprianto, E. (2011). Akuntansi Perpajakan. Yogyakarta: Graha Ilmu.

Umar, H. (2013). Metode Penelitian Untuk Skripsi dan Tesis Bisnis. Jakarta: PT RajaGrafindo Persada.

Weygrandt, J. J., Kimmel, P. D., \& Kieso, D. E. (2018). Accounting Principles. Danvers: John Wiley \& Sons, Inc.

Wijayanti, S. (2016). Pengaruh Beban Pajak Tangguhan Terhadap Persistensi Laba dan Manajemen Laba Pada Perusahaan Manufaktur. Jurnal Akuntansi AKUNESA.

Wild, J. J., \& Shaw, K. W. (2018). Fundamental Accounting Principles. McGraw-Hill Education. 